\title{
A STUDY OF PSYCHIATRIC FACTORS IN PATIENTS PRESENTED WITH ATTEMPTED SUICIDE IN A STATE CAPITAL MEDICAL COLLEGE HOSPITAL IN CENTRAL INDIA
}

Keshav Singh ${ }^{1}$, Karuna Jindwani2, Ram Narayan Sahu ${ }^{3}$, Ram Singh Maniram ${ }^{4}$, Tribhuvan Nath Dubey5, Virendra Kumar Sharma ${ }^{6}$

${ }^{1}$ Assistant Professor, Department of Medicine, Shyam Shah Medical College, Rewa, M. P.

${ }^{2}$ Assistant Professor, Department of Dentistry, Gajara Raja Medical College, Gwalior, M. P.

3 Professor \& HOD, Department of Psychiatry, Gandhi Medical College, Bhopal, M. P.

${ }^{4}$ Assistant Professor, Department of Medicine, Gandhi Medical College, Bhopal, M. P.

5 Professor \& HOD, Department of Medicine, Gandhi Medical College, Bhopal, M. P.

${ }^{6}$ Professor \& HOD (Retd.), Department of Medicine, Gandhi Medical College, Bhopal, M. P.

\section{ABSTRACT}

Suicide is one of the commonest psychiatric emergencies. According to WHO report, 1999 suicide was one of the top three leading causes of death among people aged 15-34 years in all countries. In recent years, attempted suicide has become the focus of research as it has been found to be the predictor of suicide. Psychiatric factors are one of the important determinants in attempted suicide.

\section{OBEJCTIVES}

The aim of the present study was to analyse the psychiatric factors in attempted suicide.

\section{METHODS}

The present study was conducted in the Department of Medicine and Department of Psychiatry, Gandhi Medical College and associated Hamidia Hospital Bhopal. Study based on the patients admitted in Medicine/Psychiatry ward or attending Out Patients Department with history of suicidal attempts, during the period December 2006 to November 2007.

\section{RESULTS}

Psychiatric disorders were present in $74.25 \%$, while no psychiatric disorder was present in rest of $25.75 \%$.

\section{CONCLUSION}

Major depressive disorder accounting for $34.69 \%$ cases, was the most common concurrent psychiatric illness among the study group.

\section{KEYWORDS}

Psychiatric Factor, Attempted Suicide, Major Depressive Disorder.

HOW TO CITE THIS ARTICLE: Singh K, Jindwani K, Sahu RN, et al. A study of psychiatric factors in patients presented with attempted suicide in a state capital medical college hospital in central India. J Evolution Med Dent Sci 2016;5(2):117-119, DOI: $10.14260 /$ jemds/2016/29

\section{INTRODUCTION}

Suicide as an issue, has attracted the attention of society since time immemorial. As compare to completed suicide it is much more difficult to acquire information regarding attempted suicide or deliberate self-harm. According to WHO statistics, the annual worldwide incidence of completed suicide was 16 per 100000 in 1995, which accounts for 1-2\% of global mortality.[1] Attempted suicide occurs 6-8 times more often than completed suicide. [2] In recent years, attempted suicide has become the focus of research as it has been found to be the predictor of suicide. [3] In India about 100000 persons commit suicide every year, contributing to about $10 \%$ of suicide in the world. ${ }^{44]}$ Suicide is among the top 10 causes of death in India and the top 3 causes of death in those between 16 and 35 years of age.[5] The national suicide rate for 2001 was 10.6 per 100000 population, a $14.5 \%$ increase from 1991.[5]

Financial or Other, Competing Interest: None.

Submission 17-12-2015, Peer Review 18-12-2015,

Acceptance 02-01-2016, Published 06-01-2016.

Corresponding Author:

Dr. Keshav Singh,

Assistant Professor,

Department of Medicine,

Shyam Shah Medical College,

Rewa, Madhya Pradesh.

E-mail: keshavsingh19@yahoo.com

DOI:10.14260/jemds/2016/29
There are considerable regional differences in the rate of suicide in different parts of India.

\section{METHOD}

This was a cross-sectional study conducted at Gandhi Medical College and associated Hamidia Hospital, Bhopal from December 2006 to November 2007. Patient attending out patients department or admitted in the Department of Medicine or Psychiatry were included in the study. A total number of 66 patients were evaluated with detailed psychiatric interview including a detailed psychiatric history; mental status examination on a specially designed proforma. After strict exclusion criteria, patients and their family who have consented to actively participate in the study were form the study group. Patients who were not in a condition for psychiatric interview, whose information was inadequate or refused to give consent were excluded.

\section{RESULTS}

Psychiatric disorder were present in 49 (74.25\%), while no psychiatric disorder was present in the rest of the cases 17 (25.75\%). Amongst the male, psychiatric disorder was present in 19 (76\%), while in females, 30 (73.18\%) have psychiatric disorders. 
Presence or Absence of Psychiatric Disorders ( $N=66)$

\begin{tabular}{|c|c|c|c|c|c|}
\hline & \multicolumn{2}{|c|}{$\begin{array}{c}\text { Male } \\
\text { (n=25) }\end{array}$} & \multicolumn{2}{c|}{$\begin{array}{c}\text { Female } \\
\text { (n=41) }\end{array}$} & \multirow{2}{*}{ Total } \\
\cline { 2 - 5 } & No. & $\mathbf{\%}$ & No. & \% & \\
\hline $\begin{array}{c}\text { Without } \\
\text { psychiatric illness }\end{array}$ & 6 & 24 & 11 & 26.82 & 17 \\
\hline $\begin{array}{c}\text { With psychiatric } \\
\text { illness }\end{array}$ & 19 & 76 & 30 & 73.18 & 49 \\
\hline
\end{tabular}

Among the psychiatric disorders associated with suicidal attempts, Major depressive disorder was present in 17 $(34.69 \%)$ of total, in males $7(36.84 \%)$ and females 10 $(33.33 \%)$

\begin{tabular}{|c|c|c|c|c|c|}
\hline & \multicolumn{2}{|c|}{$\begin{array}{c}\text { Male } \\
(n=19)\end{array}$} & \multicolumn{2}{|c|}{$\begin{array}{c}\text { Female } \\
(n=30)\end{array}$} & \multirow[t]{2}{*}{ Total } \\
\hline & No. & $\%$ & No. & $\%$ & \\
\hline $\begin{array}{l}\text { Major depressive } \\
\text { disorder }\end{array}$ & 7 & 36.84 & 10 & 33.33 & 17 \\
\hline $\begin{array}{c}\text { Bipolar disorder } \\
\text { NOS }\end{array}$ & 2 & 10.52 & 3 & 10.00 & 5 \\
\hline $\begin{array}{c}\text { Impulse control } \\
\text { disorder NOS }\end{array}$ & 2 & 10.52 & 6 & 20.00 & 8 \\
\hline $\begin{array}{c}\text { Adjustment } \\
\text { disorder } \\
\text { unspecified }\end{array}$ & 2 & 10.52 & 4 & 13.33 & 6 \\
\hline $\begin{array}{c}\text { Histrionic } \\
\text { personality } \\
\text { disorder }\end{array}$ & - & - & 1 & 03.33 & 1 \\
\hline $\begin{array}{c}\text { Personality } \\
\text { disorder NOS }\end{array}$ & 2 & 10.52 & 1 & 03.33 & 3 \\
\hline $\begin{array}{c}\text { Obsessive- } \\
\text { compulsive } \\
\text { disorder }\end{array}$ & - & - & 1 & 03.33 & 1 \\
\hline Schizophrenia & 1 & 05.26 & 1 & 03.33 & 2 \\
\hline $\begin{array}{c}\text { Multiple substance } \\
\text { abuse }\end{array}$ & - & - & 1 & 03.33 & 1 \\
\hline $\begin{array}{c}\text { Alcohol } \\
\text { dependence }\end{array}$ & 3 & 15.78 & - & - & 3 \\
\hline $\begin{array}{c}\text { Dissociative } \\
\text { disorder }\end{array}$ & - & - & 1 & 03.33 & 1 \\
\hline $\begin{array}{c}\text { Delusional } \\
\text { disorder }\end{array}$ & - & - & 1 & 03.33 & 1 \\
\hline
\end{tabular}

Bipolar disorder NOS were present in $5(10.20 \%)$ of total, in males $2(10.52 \%)$ and females $3(10.00 \%)$. While Impulse control disorder NOS was present in $8(16.32 \%)$ of total, in males $2(10.52 \%)$ and females $6(20.00 \%)$. Adjustment disorder unspecified was present in $6(12.24 \%)$ of total, in males $2(10.52 \%)$ and in females $4(13.33 \%)$. Histrionic personality disorder was present in $1(2.04 \%)$ of total, it was in females $1(3.33 \%)$. Personality disorder NOS was present in $3(6.12 \%)$ of total, in males $2(10.52 \%)$ and in females 1 (3.33\%).

Obsessive compulsive disorder was present in $1(2.04 \%)$ of total, it was in females 1 (3.33\%). Schizophrenia was present in $2(4.08 \%)$ of total, in males $1(5.26 \%)$ and in females $1(3.33 \%)$. Multiple substance abuse was present in $1(2.04 \%)$ of total, it was in females 1 (3.33\%). Alcohol dependence was present in $3(6.12 \%)$ of total and it was in males $3(15.78 \%)$. Dissociative disorder was present in $1(2.04 \%)$ of total, it was in females 1 (3.33\%). Delusional disorder was present in $(2.04 \%)$ of total, it was in females 1 (3.33\%).

\section{DISCUSSION}

In the present study according to the Diagnostic and Statistical Manual, approximately $74.25 \%(n=49)$ patients were found to have concurrent psychiatric illness while remaining $25.75 \%$ were without illness. Similar higher prevalence was reported in study by Latha et al.[6] while studies by Shrivastava et al.[7] Chandrasekaran et al.[8] Jain et al.[9] Sethi et al.[10] have recorded much lower prevalence.

In the present study among the concurrent psychiatric illness the most common was major depressive disorder accounting for $34.69 \%$ cases, followed by impulse control disorder NOS $16.32 \%$, adjustment disorder unspecified $12.24 \%$, bipolar disorder NOS $10.20 \%$, personality disorder NOS 6.12\%, alcohol dependence 6.12\%, Schizophrenia 4.08\%, histrionic personality disorder $2.04 \%$, obsessive compulsive disorder 2.04\%, dissociative disorder $2.04 \%$. Similar dominance of depressive disorder was found in study done by Bhatia et al.[11]

According to Sanjush Baby et al.[12] found that majority of subjects had a psychiatric diagnosis (91\%), adjustment disorder $(40 \%)$ was the commonest followed by depression (28\%), which was the next most common diagnosis, then alcohol dependence (10\%). Other psychiatric illness were schizophrenia $(3.07 \%)$, grief reaction $(1.53 \%)$, antisocial personality $(0.77 \%)$, multiple substance abuse $(0.77 \%)$.

In the study conducted by Sarkar P, Sattar FA et al.[13] found that, $70 \%$ of those attempting suicide were suffering from stress related illness with prominent histrionic traits in personality, 20\% were suffering from mild depression and the remaining $10 \%$ were suffering from dysthymia and dissociative disorder.

\section{CONCLUSION}

The pathways to suicidal behaviour are often long and complex. Therefore, treatment and prevention of suicidal behaviour require attention to a range of broad and specific strategies. A range of psychiatric disorders are found in suicide attempters. Effective treatment of such individuals will result in reduction of attempted suicide.

\section{REFERENCES}

1. Lonnqvist JK. Epidemiology and causes of suicide. In: Gelder et al. new oxford textbook of Psychiatry, vol 1, $1^{\text {st }}$ edn, Oxford University Press; 2000. P.1033-1038.

2. Williams JMG, Pollock LR. Factors mediating suicide behaviour: their utility in Primary and Secondary Prevention. Journal of mental health 1993;2:3-26.

3. Howton K, Fagg J. Suicide and the other causes of death following attempted suicide. $\mathrm{Br} \quad \mathrm{J}$ Psychiatry 1988;152:359-366.

4. Vijayakumar L. Suicide prevention: The urgent need in developing countries. World psychiatry 2004;3:158-9.

5. Government of India. National Crime Record Bureau 2002.

6. Latha KS, Bhat SM, D'Souza P. Suicide attempters in a general hospital unit in India: Their socio-demographic and clinical profile-emphasis on cross cultural aspects. Acta Psychiatr Scand 1996;94:26-30.

7. Shrivastava MK, Sahoo RN, Ghotekar LH, Shrhari Dutta, DM, Dutta TK, Das AK. Risk factors associated with attempted suicide: A case-control study. Indian J Psychiatry 2004;46(1):33-38. 
8. Chandrasekaran R, Gnanaseelan J, Sahai A, et al. Psychiatric and personality disorder in survivors following their first suicide attempt. Indian J Psychiatry 2003; 45(11):45-48.

9. Jain V, Singh H, Gupta SC, et al. A study of hopelessness, suicidal intent and depression in cases of attempted suicide. Indian J Psychiatry 1999; 41(2):122-130.

10. Sethi BB, Gupta SC, Singh H. Psychosocial factors and personality characteristics in cases of attempted suicide. Indian J Psychiatry 1978; 20:25-30.
11. Bhatia MS, Aggrawal NK, Aggrawal BB. Psychosocial profile of suicide ideators, attempters and completers in India. International Journal of Social Psychiatry 2000; 46(3):155163.

12. Sanjush Baby, Manju P Haridas and Yesudas KF. Psychiatric diagnosis in attempted suicide. Calicut Medical Journal 2006; 4(3):e2.

13. Sarkar P, Sattar FA, Gode N, et al. Failed suicide and deliberate self-harm. Indian Journal of Psychiatry 2006; 48(2):78- 83. 